American University Washington College of Law

Digital Commons @ American University Washington College of

Law

Articles in Law Reviews \& Other Academic Journals

Scholarship \& Research

2000

The Norm of Justice and the Negotiation of the Rambouillet/Paris

Peace Accords

Paul Williams

Follow this and additional works at: https://digitalcommons.wcl.american.edu/facsch_lawrev

Part of the International Law Commons, and the Military, War, and Peace Commons 


\title{
The Norm of Justice and the Negotiation of the Rambouillet/Paris Peace Accords
}

\author{
Paul R. Williams*
}

Keywords: Kosovo; peace agreements; Rambouillet agreements; conflict resolution; minority rights.

\begin{abstract}
With the creation of the International Criminal Tribunal for the Former Yugoslavia and the imminent creation of a permanent International Criminal Court, as well as the proliferation of public statements by high government officials endorsing the norm of justice, many commentators are hypothesizing that the long running tension between peace and justice may be undergoing a period of reconciliation. A brief review of the efrorts to incorporate the norm of justice in the Rambouillet/Paris Accords and UNSC 1244 indicates that only minimal progress has been made in the reconciliation between the quest for a negotiated peace and the norm of justice.
\end{abstract}

As the most powerful nation committed to the rule of law, we have a responsibility to confront these assaults on humankind. One response mechanism is accountability, namely to help bring the perpetrators of genocide, crimes against humanity, and war crimes to justice. If we allow them to act with impunity, then we will only be inviting a perpetuation of these crimes far into the next millennium. Our legacy must demonstrate an unyielding commitment to the pursuit of justice.

\section{David Scheffer \\ US Ambassador for War Crimes ${ }^{1}$}

The search for a juster peace than was obtainable at the negotiating table has inflicted hardship and havoc on innocent civilians within the former Yugoslavia and exacted a heavy price from the already weak economies of the neighboring states.

David Owen

Co-Chair of the International Conference for the former Yugosiavia ${ }^{2}$

\footnotetext{
* Assistant Professor of Law and International Relations, American University; Ph,D. University of Cambridge, J.D. Stanford Law School, A.B. UC Davis; Legal Adviser to the Kosovar Delegation during the Rambouillet/Paris Negotiations, and to the Bosnian Delegation during the Dayton Negotiations; served in the United States Department of State's Office of the Legal Advisor for European Affairs from 1991-1993.

I. Speech presented by Ambassador David Scheffer at Dartmouth University (23 October 1998).

2. D. Owen, Balkan Odyssey 365 (1995).
}

13 Leiden Journal of International Law 207-217 (2000)

C) 2000 Kluwer Law Intemational 


\section{INTRODUCTION}

With the creation of the International Criminal Tribunal for the Former Yugoslavia (Yugoslav Tribunal) and the imminent creation of a permanent International Criminal Court, as well as the proliferation of public statements by high government officials endorsing the norm of justice, such as the one by David Scheffer immediately above, many commentators are hypothesizing that the long running tension between peace and justice may be undergoing a period of reconciliation. ${ }^{3}$ This article examines the negotiation of the Rambouillet/Paris Accords to test whether there is in fact an emerging reconciliation, or whether justice is still perceived of as a hindrance to the process of peace building, and is merely being more frequently incorporated into the rhetoric of diplomacy, while still marginalized in the negotiation process.

\section{BACKGROUND}

In February 1999, after the collapse of the Holbrooke/Milošević October 1998 cease-fire arrangement, the Serbian regime continued its preparations for full scale ethnic cleansing and genocide in Kosova. In response to the growing atrocities, the international community convened a peace conference in Rambouillet, France, under the threat of NATO airstrikes, with a follow-up conference in Paris. The parties to the peace conference included a Kosovar delegation, with representatives from the shadow government, the Kosova Liberation Army, and the intelligencia; a Serbian delegation, with representatives from the Serbian central government (two of which were subsequently indicted for war crimes committed before and during the Rambouillet/Paris peace process), members of the non-Serbian ethnic minority in Albania, and legal experts (notably, Slobodan Milošević was not present at the negotiations); representatives of the Contact Group, including the United States, France, Germany, Russia, Italy and Great Britain; and representatives of the European Union and OSCE. The Rambouillet/Paris negotiations were Co-hosted by the French and British Foreign Ministers, and chaired by the United States, Russia and the European Union. Although the Rambouillet/Paris Accords never formally entered into force they did provide the basis for much of the substance adopted in UN Security Council Resolution 1244 which established the framework for peace implementation in Kosova by the international community.

3. See N. Roht-Arriaza, Conchsion: Combating Impunity, in N. Roht-Arriaza (Ed.), Impunity and Human Rights in International Law and Practice (1995); M. Scharf, The Case for A Permanent International Truth Commission, 7 Duke J. Compar. \& Int'1 L. 375 (1997); RJ. Goldstone, Justice as a Tool for Peace-Making: Truth Commissions and International Criminal Tribunals, 28 NYU J. Int'1 L. \& Pol. 485 . 
Notably, during the negotiation of the Dayton Accords, despite the fact the various parties to the negotiations held differing views as to the role of justice in promoting peace, there was some minimal consensus the Accords should create obligations to bring war criminals to justice. In the case of the Rambouillet/Paris negotiations, however, there were few public declarations by any of the parties, or the Tribunal, prior to the negotiations concerning the role of justice. In fact, during the course of the negotiations there was considerably more opposition to including detailed provisions relating to the obligation to cooperate with the Tribunal and apprehend indicted war criminals.

\section{Negotiating Peace (and Justice?)}

\subsection{The nature of the Rambouillet/Paris Accords}

Like the Dayton Accords, the final version of the Rambouillet/Paris Accords reflects only a minimal recognition of the obligation of the parties to employ the norm of justice. This minimal reflection is in large part a result of the tension during the negotiations between those participants who desired a quick peace deal in order to avoid the necessity of air strikes, (most notably the French and German delegations), those who believed it might be possible to secure a deal if Serbian interests could be sufficiently accommodated (most notably the Russian delegation, and some members of the American delegation) and those who sought a peace package - that is a structured set of commitments which, if fulfilled, could promote a meaningful peace in Kosova (the Kosovar delegation, the European Union Co-Chair, and some members of the British delegation).

The Rambouillet/Paris negotiations were qualitatively different from the Dayton negotiations in that by the time of the crisis in Kosova, the work of the Yugoslav Tribunal had established a clear pattern of war crimes and genocide against the civilian population during the Bosnian war, and recent reports by the Kosovo Verification Mission credibly indicated a similar pattern was occurring in Kosova. In addition, many members of the British political establishment, civilian and military leaders in the NATO chain of command, and a few American officials believed that it would be necessary to use force to stop continued ethnic aggression in Kosova and that the peace talks were a necessary part of the political process prior to the initiation of airstrikes.

In addition, there were four other important differences. First, there had been a transfer of political power in the United Kingdom from the Tory party to the Labour party, accompanied by the emergence of a significantly stronger commitment to the norm of justice, and by a lessening of allegiance with Serbia. Second, the talks were held in France, which gave the French government significantly more influence over the procedural aspects of the peace negotiations than during the Dayton negotiations. Third, the Russian delegation, while not 
necessarily exercising more influence over the substance of the negotiations, did exercise a higher political profile, and did protect Serbian interests on a number of important matters. And fourth, the Serbian delegation adopted a strategy of presenting itself as unconcerned as to whether a negotiated settlement would be reached.

\title{
3.2. War crimes provisions proposed by the Kosovar delegation
}

Early in the course of the Rambouillet/Paris negotiations, the Kosovar Delegation proposed a number of additions to the draft text concerning the norm of justice and in particular the need to ensure the adequate investigation of war crimes and the subsequent apprehension and extradition of all indicted individuals. ${ }^{4}$ Given the path of moral equivalence adopted by many members of the international community during the Bosnian conflict, the Kosovars also expressed concern about the necessity of creating an accurate historical record in order to deter the invocation of similar moral equivalence in their case.

- To remove any ambiguity as to the responsibility of the parties to cooperate with the Yugoslav Tribunal and to arrest and extradite to the Hague all those indicted, the Kosovars proposed that the accords include language to the effect that,

\begin{abstract}
The parties to this agreement agree to discharge their obligation towards the International Criminal Tribunal on the Former Yugoslavia pursuant to all relevant Security Council resolutions. Consistent with these resolutions, the parties agree to arrest, detain, and transfer to the custody of the International Criminal Tribunal for Yugoslavia any and all persons indicted by the International Criminal Tribunal for the Former Yugostavia who reside in or transit through or are otherwise present in Kosova, Serbia and the Federal Republic of Yugoslavia.
\end{abstract}

- Concemed about the non-implementation of a general obligation to cooperate in the Dayton Accords, and the refusal of the Serbian government to date to cooperate with the Yugoslav Tribunal, the Kosovar delegation further proposed the inclusion of language stating that, "The parties further commit to provide any judicial assistance requested by the Tribunal, e.g. taking of testimony, access to and production of evidence, access to any person, facility, document and area of territory, as well as the service of documents."

- To create a benchmark for measuring cooperation with the Yugoslav Tribunal and to challenge the Serbian regime on a loophole in the Security

4. See Proposed Changes to the Rambouillet Accords, Kosovar Delegation (February 1999) (on file with the author). 
Council Resolutions which they frequently invoked to deny Yugoslav Tribunal investigators access to Kosova to investigate crimes - against both Kosovar Serbs and Kosovar Albanians, and to ensure security for the investigators, the Kosovar delegation proposed that, "All Yugoslav Tribunal personnel shall be entitled to immediate and visa-free entry into Montenegro, Serbia and Kosova, and shall be free to conduct unfettered investigations. NATO shall, were appropriate, escort Tribunal personnel."

- To clearly establish that NATO possessed all necessary authority, and an obligation, to implement the norm of justice, the Kosovar delegation further proposed that the accords clearly state, "NATO shall be responsible for the enforcement of these provisions, including the use of force under the NATO Activation Order."

- Aware of the previous non-compliance with the Dayton Accords and relevant Security Council resolutions mandating cooperation with the Tribunal, the Kosovar delegation also proposed,

In the event a party fails to cooperate fully with the International Criminal Tribunal on the Former Yugoslavia and its organs in accotdance with the Security Council resolutions, they shall be subject to economic and other sanctions as provided for by the Security Council. The application of such sanctions shall not prejudice states, acting individually or collectively, from imposing additional or supplemental sanctions on the parties for failing to comply with their obligations with respect to the arrest, detention, and transfer any and all persons indicted by the International Criminal Tribunal for the Former Yugoslavia.

- Finally, the Kosovar delegation sought to significantly enhance the application of the norm of justice by providing the Yugoslav Tribunal with the authority to dictate when sanctions may be removed. Specifically, the delegation proposed,

Existing sanctions may not be removed until the President of the Yugoslav Tribunal has certified that all parties are cooperating fully with the Tribunal and had accepted its jurisdiction, in principle and in practice, as demonstrated by the extradition to The Hague of all suspected war criminals indicted by the Yugoslav Tribunal who are present on the territory of the FRY, and that visafree access has been provided to personnel of the Tribunal.

\subsection{War crimes provisions proposed by the Serbian delegation}

During the first week and a half of the Rambouillet/Paris negotiations, the Serbian delegation refused to engage on the substantive issues of the negotiation, rather they raised a number of procedural concerns and objected to the fundamental structure and nature of negotiations. When the Serbian delegation did engage on the substantive issues, they set forth five primary objectives. The fifth 
of these was that there be no mention of the Tribunal in the Accords. Subsequently during the Paris phase of the negotiations, the Serbian delegation submitted a written counter proposal to the Contact Group proposal. The Serbian counter proposal contained a red-lined deletion of the three paragraphs mentioning cooperation with the Tribunal, and the paragraph prohibiting indicted or convicted war criminals from holding public office. The Serb proposal also deleted in their entirety the Military, Police, and Humanitarian Assistance Annexes. ${ }^{5}$

One possible explanation for the rather severe reaction to the Yugoslav Tribunal by the Serbian delegation was that the chair and vice chair of the delegation, Mr. Milan Milutinović, and Mr. Nikola Sainović, were likely responsible for orchestrating much of the ethnic cleansing and attempted genocide in Kosova, and were in fact subsequently indicted by the Yugoslav Tribunal, ${ }^{6}$ and named as defendants in a civil suit brought by Kosovar refugees in the United States charging the two men, among others, with conspiracy to commit genocide. $^{7}$

\subsection{Response of the international community}

A few members of the Contact Group supported the proposals of the Kosovar Delegation - in particular the European Union representative, while others reacted coolly or dismissively $\rightarrow$ the German and American representatives, while still others reacted harshly, accusing the Kosovar delegation of attempting to derail the peace process - the French and OSCE representatives, while the Russians adopted the position of the Serbian delegation. At one point for instance, the member of the Kosovar delegation responsible for negotiating the constitutional aspects of the accords requested that the term "genocide" be added to the list of matters on which the parties would have to cooperate with the Tribunal, as opposed to only war crimes and crimes against humanity. The Contact Group immediately dismissed this request on the basis that the Albanians were not being targeted for destruction as a group. (In the following May, that delegate was hauled from a refugee train and executed by Serbian security forces as part of their plan to further their genocide against the people of Kosova by executing Kosovar intellectuals).

5. Serbian Counter Proposal to the Rambouillet/Paris Accords (15 March1999).

6. Indictment against Slobodarı Milošević, Milan Milutinović, Nikola Sainović, Dragoljub Ojdanić, Vlajko Stojilković, Case No. IT-99-37, 24 May 1999.

7. John Doe I and John Doe II v. Miloševic and Others, Civil Action No. 99, filed in the United States District Court, District of Massachusetts (23 May 1999). Available at http:/www.balkanaction.orgi pubs/complaint.html.

8. For an accounting of the assassination of Professor Fehmi Agani, see M. Eddy, Kosovars Moum Death of Agani, Associated Press, 27 June 1999. 
In response to the Kosovar delegation proposals that the parties be obligated to arrest and extradite indicted war criminals and that they cooperate on specific matters of interest to the Tribunal, the Contact Group proposed more vague language to the effect,

All Parties shall comply with their obligation to cooperate in the investigation and prosecution of war crimes, crimes against humanity, and other serious violations of international humanitarian law.

(a) The Parties will allow complete, unimpeded, and unfettered access to international experts - including forensic experts and investigators from the International Criminal Tribunal for the Former Yugoslavia (ICTY) - to investigate such allegations.

(b) Pursuant to the terms of UN Security Council Resolution 827 and subsequent resolutions, the Parties shall provide full support and cooperation for the activities of the ICTY, including complying with its orders and requests for information, and facilitating its investigations.

No rationale was given for this more vaguely worded language other than to indicate that the Serbian delegation and the Russian representatives were opposed to any mention of the Tribunal and that this language was likely to be the best on which the parties could reach agreement. Subsequently this language was modified to provide,

All Parties shall comply with their obligation to cooperate in the investigation and prosecution of serious violations of international humanitarian law.

(a) As required by United Nations Security Council resolution 827 (1993) and subsequent resolutions, the Parties shall fully cooperate with the International Criminal Tribunal for the Former Yugoslavia in its investigations and prosecutions, including complying with its requests for assistance and its orders.

(b) The Parties shall also allow complete, unimpeded, and unfettered access to international experts including forensic experts and investigators to investigate allegations of serious violations of international humanitarian law. ${ }^{10}$

Although these changes were made at the request of the Serbian and Russian delegations, the American co-chair strove to indicate that they were in fact improvements on the original language. In fact, the new language deleted reference to war crimes and crimes against humanity, continued to omit the reference to genocide, and deleted the specific obligation to cooperate with forensic experts

9. Draft Rambouillet/Paris Accords, Framework Agreement, para. 14 (6 February 1999).

10. First included in Draft Rambouillet/Paris Accords, Framework Agreement, para. 11, (18 February 1999). Included in final Rambouillet/Paris Accords, Framework Agreement, para. 13, (23 February 1999). 
and investigators from the Tribunal, while retaining only the vague commitment to "fully cooperate" with the Tribunal. The new language also deleted the obligation to comply with the Tribunals' request for information and to facilitate its investigations.

The draft and final Accords also incleded a provision which prohibited any person indicted by the Tribunal or serving a sentence from standing as a candidate or holding any office. ${ }^{11}$

Aware that the Serbians and Russians were mounting and attempt to delete any reference to the Tribunal, and that the European members of the Contact Group were only weakly committed to the inclusion of a reference to the Tribunal, let alone committed to using the document as a means of enhancing the norm of justice, the Chief Judge of the Tribunal, Gabrielle Kirk McDonald, sent a letter to the Co-Hosts of the Peace Conference, Foreign Minster Cook and Foreign Minister Vedrine and called a press conference, wherein she expressly declared the need to reference the work of the Tribunal and to enhance the prospects for a meaningful role for the norm of justice. Specifically, she declared in her letter that she was worried about reports that the draft text of the Rambouillet/Paris Accords did not contain provisions that would specifically "require [the parties] to recognize the competence of the International Tribunal (Tribunal) or to take specific measures to co-operate with the Tribunal," but would rather only require them to agree to "a general provision on co-operation." 12

The President of the Tribunal then went on to explain that given the attitude of Serbia/Montenegro to the Tribunal, "as demonstrated by its record of non-cooperation with and obstruction of Tribunal requests and orders," she believed that "such a generic provision is not sufficient to ensure that the Tribunal will be able to discharge its mandate."13 She then invoked the expressed commitment of France and the United Kingdom to an effective Tribunal to personally ask the Foreign Ministers to ensure that the Accords contained express references to the obligation of the parties to recognize the jurisdiction of the Tribunal and to facilitate specific activities, including its legal right to access Kosova and to conduct investigations there. The President of the Tribunal concluded with the declaration that "it is axiomatic that there can be no peace without justice," and that any agreement which failed to bind the parties to specific forms of co-operation "risks being perceived as sacrificing the principles on which the Tribunal is founded for short-term political interest.."14

The efforts of the Chief Judge were slightly undermined by the Deputy Prosecutor, who upon hearing that reference to the Tribunal might be deleted or weakened reacted in a relatively naïve fashion by sending a letter to the Co-

11. Rambouillet/Paris Accords, Constitution, Art. 1, para. 9 (23 February 1999).

12. Letter from President McDonald to Foreign Ministers Vedrine and Cook Concerning the Kosovo Negotiations at Rambouillet, France (22 February 1999).

13. Id.

14. Id. 
chairs of the conference indicating that he would prefer no reference to the Tribunal rather than some weakened reference, as he believed that previous Security Council resolutions offered sufficient authority for the work of the Tribunal. Notably, the Chief Prosecutor was in Africa at the time of this letter, and it is widely believed that she would not have approved of its content, but rather would have supported the approach of Justice McDonald as she recognized that to date the Security Council authorization, while legally sufficient, did not produce the desired compliance by the Serbian regime, and that it was necessary to improve upon the mandate of the Tribunal and partner organizations, such as NATO, and to more fully detail the obligations of the parties to the conflict.

Despite the efforts of the Chief Judge, all of the other proposed changes by the Kosovar delegation were expressly rejected. The provisions relating to the granting of visa free access and escorts by NATO personnel were seen by representatives of the OSCE and German delegations as unnecessarily antagonistic of the Serbian regime and likely to produce a political backlash. Interestingly, the delegates who conveyed these messages seemed to be under the impression that the Serbian government did not intend meaningful cooperation with the Yugoslav Tribunal no matter which provisions were included in the Accords, and thus it was unnecessary and inconvenient to propose such specific principles which would give the Serbian delegation an opportunity to object to the Accords. This approach was reminiscent of the "peace deal" approach pursues by some governments during the Dayton negotiations.

Concerning the proposal that NATO be specifically identified as possessing responsibility for enforcing the provisions of the accord relating to war crimes, the members of the Contact Group again objected on the basis that such a reference would unnecessarily antagonize the Serbian delegation. In fact, any references to NATO in Kosovar proposals, as well as repeated calls for a meeting with NATO officials during the peace talks, were rebuffed by the Americans, French and British as NATO was not to be present during the Rambouillet/Paris negotiations out of deference to the wishes of the French hosts. Unfortunately, what was a basic misjudgment as to the policy dynamics amongst presumed allies - excluding NATO from the negotiations (until the last possible moment when the Kosovars refused to negotiate until they were briefed by General Wesley Clark) also impacted the substance of the provisions of the accords relating to the operation of the Tribunal.

Similarly, the attempt of the Kosova delegation to link sanctions to compliance with the obligation to cooperate with the Tribunal and to essentially provide the Tribunal with veto authority over the lifting of sanctions was considered a policy "non-starter" by the European governments who had grown tired of sanctions, and in particular the Italians who had invested heavily in Serbian infrastructure since the end of the Bosnia war and who intended, along with the Greeks to continue such investment. Even the British government was reluctant to support the adoption of a program for automatic sanctions or for an enhance- 
ment of the power of the authority of the Yugoslav Tribunal out of deference to its European allies with more significant financial interests in Serbia. Moreover, certain members of the Contact Group, although not the United States, were quite interested in embarking an a program of economic inducements to encourage Serbia to comply with the Rambouillet/Paris Accords in the event of their signature.

\section{Decreeing Peace - United Nations Security Council RESOLUTION 1244}

Despite the efforts of the Contact Group members to induce Serbia into signing the Rambouillet/Paris Accords, the Serbian delegation refused to accept the terms of the agreement. The Kosovars too had difficulty accepting the agreement and required a two week suspension of the talks in order to consult with the people of Kosova. Upon returning to Paris for the second round of talks the Kosovar delegation signed, while the government of Serbia refused to sign and continued to carry out its campaign of ethnic cleansing and genocide against the Kosovar Albanians. Upon the collapse of the Accords and the intensification of the ethnic aggression, NATO launched a series of increasingly intense airstrikes against Yugoslav forces in Serbia and Kosova, as well as Serbia's civil and military infrastructure. After over seventy days of airstrikes and an increasing willingness of NATO forces to commit ground troops to the conflict, the government of Serbia agreed to peace. The terms of the peace were set out not within the Rambouillet/Paris Accords, but rather within United Nations Security Council resolution 1244 adopted on June 10, 1999.

During the course of negotiating the resolution there was much debate as to the extent to which war crimes related matters would be referenced in the resolution. Although neither of the parties were invited to comment on the substance of the resolution, the United States, France and Great Britain supported the inclusion of at least a minimal reference to the Tribunal, while the Russians objected. The leadership of the Tribunal also conveyed a request to the Security Council that its authority be referenced, and that the parties be instructed to cooperate with the Tribunal.

After much negotiation, the resolution was drafted to include two references to the Tribunal. The first reference appears in the preamble and recalls "the jurisdiction and the mandate of the International Tribunal for the Former Yugoslavia."15 The second appears in paragraph 14 and "demands full cooperation by all concerned, including the international security presence, with the International Tribunal for the Former Yugoslavia." ${ }^{\text {"16 }}$ Although the nature of the security force

15. UN Doc. S/RES/1244 (1999).

16. $I$. . 
envisioned by the Security Council removed the need to articulate specific details concerning the ability of Yugoslav Tribunal investigators to enter Kosova without a visa and to obtain access to sites of suspected crimes, the Security Council missed an opportunity to craft a sanctions regime which would have empowered the Tribunal to compel compliance with its orders and to obtain access to Serbia proper. Again though, such a regime would have had little chance of being adopted given the Russian and French opposition.

\section{Conclusions}

This brief review of the efforts to incorporate/exclude the norm of justice from the Rambouillet/Paris Accords indicates that only minimal progress has been made in the reconciliation between the quest for a negotiated peace and the norm of justice. In particular, the primary actors in the peace building process in the former Yugoslavia continue to view the norm of justice as a hindrance to their efforts to achieve peace, and seek to incorporate the norm only so far as is required to continue the justification of their public rhetoric. At times the peace builders found themselves constrained only by previous public commitments to justice made by their respective government.

Similarly, although the negotiators find themselves compelled to mention the existence of the Yugoslav Tribunal and to urge cooperation with the Tribunal, they are unwilling to employ the negotiation process as a means for enhancing the ability of the Tribunal to carry out its functions, or to provide the Tribunal with the ability to interfere in the implementation of the negotiated peace, by for instance triggering automatic sanctions. In fact the institutions associated with the norm of justice are perceived to have value to the extent they further the short term policy objectives of the peace-deal-makers, but there seems to be little understanding of their inherent value in sustaining a long term peace.

And finally, it is unsettling the extent to which the peace-deal-makers fail to acknowledge that their interlocutors may be responsible for war crimes, and that it may therefore be near impossible to negotiate an agreement sufficiently imbued with the norm of justice to create a basis for a real or lasting peace. The current perspective appears to be that it is better to negotiate a peace with those responsible for atrocities than to insist on the inclusion of norms of justice which may derail the peace process and limit foreign policy options to the use of force and economic sanctions. 